\title{
A critical analysis of housing inadequacy in South Africa and its ramifications
}

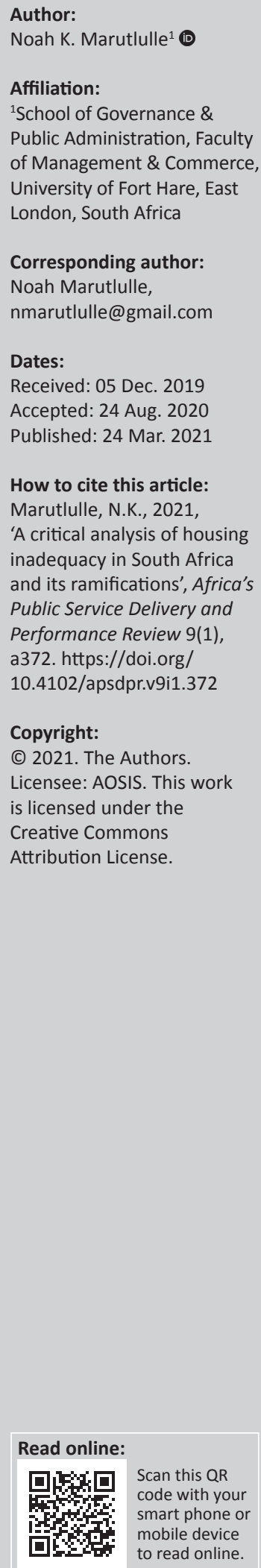

Background: This article critically analyses housing inadequacy in South Africa and its ramifications.

Aim: The study is exploratory in nature and used the qualitative methodology.

Setting: Key findings suggest that protests, informal settlements, health challenges, shack fires, flooding, violence and criminality, corruption and xenophobic attacks are the ramifications of housing inadequacy in South Africa.

Method: This study used relevant review of literature, document and policy review, and a qualitative inquiry of secondary sources with regards to housing inadequacy in South Africa and its ramifications to answer the research questions.

Results: Through the Housing Development Agency, the government needs to engage the private sector, state-owned enterprises, provinces and municipalities to unlock strategic parcels of land suitable for human settlements development, which provision, especially for low-income groups should be at subsidised rates.

Conclusion: The country needs an efficient, formidable and incorruptible department that is able to perform the huge task of spatial integration.

Keywords: housing; housing inadequacy; informal settlements; migration; population; ramifications, urban.

\section{Introduction}

The right to adequate housing is clearly recognised in international human rights law, including in the International Covenant on Economic, Social and Cultural Rights, which provides for 'the right of everyone to an adequate standard of living for himself and his family, including adequate food, clothing and housing, and to the continuous improvement of living conditions' (United Nations Publication 2012). Ademiluyi (2010) stated that in spite of the right to adequate housing being a universal right, recognised at international level and in more than 100 national constitutions throughout the world, including section 26 of chapter 2 of the South African constitution, the world is facing a global housing crisis.

The homeless and the inadequately housed are more numerous across the planet (PADCO 2006). This is corroborated by Ademiluyi (2010) who maintained that about 100 million persons are homeless and more than a billion are inadequately housed. The problem is compounding and UN-Habitat estimates that worldwide, close to 3 billion people will need access to housing and basic infrastructure services over the next 25 years (Masilela 2012), which will require 35.1 million housing units per year or 96150 per day or 4000 per hour in order to meet the demand. Every week more than a million people are born in or move to cities in the developing world, driving up the need for new and better housing (PADCO 2006). The estimates of the United Nations state that 3 billion persons will be living in slums in 2050 (Ademiluyi 2010).

It is therefore understandable that lately, housing and its related issues, particularly its inadequacy has become a serious global problem, and different countries' planners and policymakers are struggling to solve the challenges concerning the issue (Zanganeh, Varesi \& Zangiabadi 2013:180). Housing inadequacy represents a major challenge to social and economic development and places great pressure on already struggling health and education systems. The University of Dublin Trinity College (2015) concurs, maintaining that housing inadequacy places great pressure on the environment and also pose challenges to security and social cohesion.

In Africa, failure to address housing issues has led to the continued growth of slums and poorly serviced informal settlements on the urban periphery, where between $75 \%$ and $99 \%$ of urban 
residents in many African cities live in squalid slums of ramshackle housing (Carrington 2015; Giddings 2007:11). The University of Dublin, Trinity College (2015) argued that Africa currently has almost 200 million slum dwellers which account for about $20 \%$ of slums around the world and as Musewe (2012) noted, Africa is the second most populous continent and with one of the highest population growth rate in the world. With its population rocketing from 1 billion in 2015 to between 3.5 billion and 5 billion in 2100 (Carrington 2015; The University of Dublin, Trinity College 2015), African cities will have to accommodate more than 300 million new residents by 2030 (Masilela 2012).

Like many other countries in the world, South Africa is in the throes of an unprecedented housing crisis. It faces a growing challenge in providing all citizens with access to suitable or adequate housing despite the Constitution stating that 'everyone has the right to have access to adequate housing' and that the 'state must take reasonable legislative and other measures, within its available resources, to achieve the progressive realisation of this right' (Musewe 2012). According to Statistics, South Africa's Household Survey 2017, 12.1\% (1789 million households) of South Africa's 14.75 million households lived in informal housing in 2011 with Gauteng having $20.4 \%$ households living in informal settlements, North West, $18.5 \%$ and the Western Cape, 15.1\%. Limpopo has the smallest percentage with $4.5 \%$ and the Eastern Cape has $6.5 \%$ (South Africa year book 2017/18:347). Statistics of South Africa's Household Survey 2017 further stated that a total of almost 1.3 million households have no access to piped water and as far as sanitation is concerned 8242924 have flush toilets, 297847 households use bucket toilets and 748597 households have no toilet at all. The housing backlog is presently 2.1 million (Gerber 2018). All this helps to elucidate the magnitude of inadequate housing in South Africa.

According to Mullins, Western and Broadbent (2001), the nature of the relationship between housing inadequacy and socioeconomic development and cultural and political development might not be apparent because of the absence of research in the areas but there is a clear relationship between housing and crime, housing and education, housing and health, housing and social exclusion and housing and poverty. Inversely these relationships have a direct bearing on socio-economic development and also cultural and political development. It is therefore clear that the inadequacy of housing in South Africa has several diverse effects for the country.

\section{Background}

Houses reflect the most important indices of human development and therefore it is necessary for nations to invest in wholesome development and provision of citizen's housing needs (Ajayi 2012). United Nations Conference on Human Settlement United Nations Centre for Human Settlements (Habitat) and ILO 1995, United Nations Habitat (2009), United Nations Millennium Project (2005) and Millennium Development Goals recognise housing as a basic human right and commit governments to addressing housing rights (Ajayi 2012). This is because housing is one of the most fundamental basics of human needs along with food and water. It contributes to a sense of belonging, ownership, identity, citizenship and a sense of self-sufficiency (Social Work Policy Institute 2006). Housing inadequacy is therefore a major set back on humanity and has diverse effects on a country and its populace - not only the inadequately housed.

The global housing crisis, especially in the developing world, is deteriorating day by day, resulting in a situation whereby the efforts towards achieving adequate housing is becoming a mirage in spite of the ambitious United Nations Millennium Development Goal 7 Target 11 (Tibaijuka 2009). UN-Habitat (2008:3) argued that housing problems are far from being solved and submits that the problems vary from country to country and also over time, and the problems depend largely on a country's social, economic and political conditions prevailing at a given time, as well as people's attitudes towards living standards and their expectations for housing improvements.

In South Africa, substandard housing remains a legacy of apartheid over two decades after the democratic government came to power (Phago 2010). Since then, 3.3 million low-cost homes have been built, yet shanty towns have mushroomed around cities as the state programme failed to keep pace with soaring population growth. Housing Delivery in South Africa (2014:2) avers that government data show that since 1994, the population has grown to 53 million and that whilst only $15 \%$ of South Africa's 14.45 million households earn enough to secure a mortgage, $60 \%$ earn less than R3500.00 a month and can qualify for state housing. The remaining $25 \%$, including most teachers, nurses, police officers and soldiers have had access to neither. The backlog for housing according to Ministry of Human Settlement stands at 2.1 million (Phago 2010). The extent of the housing problem and the lack of delivery in the country are shown by the demand for affordable housing and by the number of people living in slums and informal housing conditions (Gilbert 2004).

This article has a comprehensive two-dimensional purpose. It seeks to analytically broaden the inquiry into housing inadequacy in South Africa and critically analyse its ramifications.

The organisation of the article is as follows:

- Introduction: This section set the article in motion and gave a brief description of the problem under review.

- Background: This section provided the background of the article.

- Methodology: This section states that the article was guided by a qualitative inquiry and provided reasons for the same.

- Literature review: This section reviewed relevant literature with regard to the housing inadequacy in South Africa and its ramifications.

- Findings: This section presented, analysed and discussed the main findings of the article and linked them to the objective of the article and the literature reviewed. 
- Conclusion: This section provided closure of the article by restating the main ideas and arguments and pulling everything together to help clarify the objective of the article.

\section{Importance of the article}

The importance of this article is that it considers the relationship between a major place-based infrastructural element and an integral part of the community fabric, which has a profound impact on the social, economic, cultural, political and physical characteristics of a community (Tariq 2012:1). Furthermore, it analyses the inadequacy of this major place-based infrastructural element and the ramifications thereof. Although there has been a great deal of research into housing, there has been relatively little on its inadequacy and the ramifications thereof (Agus, Doling \& Lee 2002).

\section{Research questions}

The questions which this article sets to answer are as follows:

- What is the context of housing inadequacy in South Africa?

- What are the causes of housing inadequacy in South Africa?

- What are the ramifications of housing inadequacy in South Africa?

- How can the problem of housing inadequacy be resolved in South Africa?

\section{Methodology}

This article adopted a qualitative methodology because it is phenomenological in nature and also that it concentrates on understanding the full-dimensional picture of the subject of investigation. Qualitative research is a term that denotes the type of inquiry in which the qualities, the characteristics or the properties of a phenomenon are examined for better understanding and explanation (Henning 2004:5). Moreover, the qualitative approach encouraged an open-ended dialogue between the researcher and the participants, which gave participants the opportunity to respond in their own words rather than having to choose from fixed responses as quantitative methods do. In addition, literature review, documentary review, including reviews of policies pertaining to housing, particularly in South Africa were conducted to assist in providing an overview of areas in which the article is disparate and interdisciplinary.

\section{Literature review}

A research project does not exist in isolation but must build upon what has been done previously. Whilst there is very little research on inadequate housing in Africa and beyond (Angel 2000) and no housing challenges theory on South Africa (White Paper on Housing 1994:5), several research studies (Arku \& Harris 2005; Baloyi 2007; Brutus 2002; Chen, Sebstad \& O'Connell 1999; Cloete 1997; Eddy 2010; Napier 1993; Power 1993; Rodwin 1987; Setplan 2008) confirm a generally opinionated view that housing inadequacy has a huge negative impact on any country and its citizens, including South Africa.

\section{Definitions for inadequate housing}

There are a number of definitions that are attached to inadequate housing. Some of them are summarised in Table 1.

The above definitions are indicative of the existence of two generic connotations attached to the term 'inadequate housing' as compared with 'adequate housing', being the desired status quo. These are:

- The excess of 'need' (not demand) for housing over supply of housing. This relates to there being more people in need of housing than the available houses. However, it is essential to clarify that in the housing context, 'need' is different from 'demand'. Housing demand refers to the willingness and ability to purchase a house and is driven by the population, whereas housing need refers to the number of houses required, given growth in households, derived from population and household size projections and makes no allowance for affordability. If those who need houses are unable to afford the houses, they do not buy or demand them.

- Shelter that is a complete negative of a central place for human life which forms an indispensable part of ensuring human dignity and encompasses more than just the four walls of a room and a roof over one's head but essential for normal healthy living, fulfilling deep-seated psychological needs for privacy and personal space; physical needs for security and protection from inclement weather; and social needs including supporting the development and social integration of its inhabitants (Morka 2018).

Whilst there are some variances across the foregoing definitions depending on context, what is prominent holistically is the emphasis that inadequate housing does not refer to only the lack of adequate shelter in terms of brick and mortar or a roof over one's head. Conversely, it means that housing should be as comfortable as possible to enhance the human's social well-being, psychological and sociological wellness (Ajayi 2012). This is the context which is consistent with this article.

\section{Causes of housing inadequacy in South Africa}

According to UN-Habitat (2015:2), housing inadequacy is caused by a range of interrelated factors, including population growth and rural-urban migration; lack of affordable housing for the urban poor; weak governance (particularly in the areas of policy, planning, land and urban management resulting in land speculation and grabbing); economic vulnerability and underpaid work; discrimination, marginalisation and displacement caused by conflict, natural disasters and climate change. Innes, Kentridge and Perold (1992:171) maintained that the increased mobility of informal dwellers and the rapid formation of shanty towns have been facilitated by administrative confusion, institutional restructuring and the absence of clear policy, all of which have left a vacuum in which squatter settlements have been able to flourish. 
TABLE 1: Definitions of inadequate housing.

\begin{tabular}{|c|c|}
\hline Authors & Definition (of inadequate housing) \\
\hline Rodgers (2001) & Housing where health, hygiene, comfort and privacy, functional and adequate physical, social and spiritual conditions are not provided. \\
\hline $\begin{array}{l}\text { Gunter and Manuel } \\
(2016: 437)\end{array}$ & The gap between self-reported availability and importance of specific interior features. \\
\hline $\begin{array}{l}\text { Raymond, Wheeler and } \\
\text { Jean-Brown (2011:21) }\end{array}$ & $\begin{array}{l}\text { Defined as an occupied housing unit that has moderate or severe physical problems, for example, deficiencies in plumbing, heating, electricity, } \\
\text { hallways and upkeep. }\end{array}$ \\
\hline Bonnefoy (2007:214) & $\begin{array}{l}\text { Housing without adequate privacy, adequate space, physical accessibility, adequate security, security of tenure, structural stability and durability; } \\
\text { adequate lighting, heating and ventilation; adequate basic infrastructure, such as water-supply, sanitation and waste-management facilities; suitable } \\
\text { environmental quality and health-related factors and adequate and accessible location with regard to work and basic facilities: all of which should be } \\
\text { available at an affordable cost. Adequacy should be determined together with the people concerned, bearing in mind the prospect for gradual } \\
\text { development. Adequacy often varies from country to country, because it depends on specific cultural, social, environmental and economic factors. }\end{array}$ \\
\hline $\begin{array}{l}\text { Housing Delivery in } \\
\text { South Africa (2014:2) }\end{array}$ & $\begin{array}{l}\text { Shelter that is not just a roof over one's head but lacks adequate privacy, adequate space, physical accessibility, adequate security, security of tenure, } \\
\text { structural stability and durability; adequate lighting, heating and ventilation; adequate basic infrastructure, such as water supply, sanitation and health } \\
\text { related factors; and adequate and accessible location with regard to work and basic facilities: all of which should be available at an affordable cost. }\end{array}$ \\
\hline Habitat and ILO (1995:2) & A form of shelter that lacks adequate privacy, space, security, lighting and ventilation, basic infrastructure and location with regard to work and basic facilities. \\
\hline $\begin{array}{l}\text { Bhandari and Wagner } \\
\text { (2006) }\end{array}$ & $\begin{array}{l}\text { Housing that is deficient in quality of basic services, materials, facilities and infrastructure, habitability, affordability, accessibility legal security of tenure } \\
\text { and location and cultural adequacy. }\end{array}$ \\
\hline UN-Habitat (2014) & Housing with physical inadequacies that relate to plumbing, heating, electricity, upkeep and lack a flushable toilet and electricity. \\
\hline $\begin{array}{l}\text { United Nations } \\
\text { Publication (2012) }\end{array}$ & $\begin{array}{l}\text { Overcrowded, high-density, poorly ventilated, damp, unclean housing, with limited access to clean water and a haphazard system of waste and water } \\
\text { disposal and that is more often than not, too cold or too hot for comfortable and healthy living. }\end{array}$ \\
\hline
\end{tabular}

This article is of the view that causes of inadequate housing are intertwined with causes of housing delivery. These are as follows:

- The Apartheid government

- Population growth (migration, urbanisation and demographics)

- Government economic policies (reconstruction and development programme [RDP], growth, employment and redistribution [GEAR] and accelerated and shared growth initiative [ASGI-SA])

- Administrative issues (municipal maladministration, lack of control and corruption)

- Economic variables (poverty, affordability and poor access to housing finance)

- Housing shortage

- Unavailability of land.

\section{The Apartheid Government}

Cloete (1997:35) posited that the present government faced great difficulties and enormous backlogs because of the apartheid legacy. This was corroborated by Malpass (1990:5) in his view that the apartheid state's lack of investment in housing created an unprecedented housing shortage and resulted in the proliferation of squatter camps and Bonner, Nieftagodien and Mathabatha's (2012:152) statement that notwithstanding the notable achievements of South Africa's housing programme over the last 23 years, the structure of South Africa's cities still carry the legacy of apartheid social engineering. Barry (2003:10) alluded that back then, massive overcrowding was inevitable. For instance, in Katlehong (a township in Johannesburg), population density in the 1980s stood at 23 to 30 per stand and a survey conducted in Thokoza in the same area in 1988 found an incredible 16 to 20 households crammed on to each stand (Bonner et al. 2012:176).

Whilst the foregoing facts are indicative that the extent of the present informal settlements challenges derives not only from the enormous size of the housing backlog and the desperation and impatience of the homeless, but stems also from the extremely complicated bureaucratic, administrative, financial and institutional framework inherited from the previous government (White Paper on Housing 1994:1), ANC (1994:23) admitted that the housing problems created by apartheid were, however, aggravated by the absence of coherent national housing policy postapartheid. Whilst Eddy (2010:3) affirmed that historical circumstances continue to affect service delivery, Brutus (2002:1) however, argued that the problems confronting many citizens today are not simply the result of historical factors - the housing crisis and other basic services are in essence a result of the pro-market policies adopted by the South African government since 1994. This assertion was corroborated by May, Carter and Padayachee (2004:18) and Mhone and Edigheji (2003:23) who alluded that the present government's policies resulted in reductions in the budget deficit and inflation against the backdrop of diminished expenditure allocations to social votes including housing. Moreover, in the period just before the end of apartheid rule, home ownership was regarded as something of a capitalist trap by many black unions who feared that it might engender more conservative ideologies amongst union membership (Innes et al. 1992:117). 


\section{Population growth}

Most of the challenges which seemingly remained unresolved since 1994 were as a result of South Africa's municipalities chasing moving targets (Bonner et al. 2012:176). Jeffery (2010:353) attributed this to inter-provincial migration and the splitting of households into smaller entities. However, Napier (1993:23) argued that the rate of population growth is more a function of natural growth than other aspects such as in-migration to urban areas. Despite stringent influx control measures to curb African urbanisation, South Africa's population grew steadily towards the end of apartheid (Bonner et al. 2012:150).

South Africa's dynamic economic development made it an important destination for work seekers. From the time the first mines started operating and the first mining villages developed, prospective miners and labourers and entrepreneurs streamed to the region in search of work or fortune (Bonner et al. 2012:117). Urban areas were created to provide places to live and work for people who could no longer make a living from farming or wanted to do something else than farming. It is accepted that urban areas, which came to be known as cities or towns were the cradles of civilisation because they served as havens for persons who wanted to invent and manufacture goods, which could enable mankind to improve its quality of life (Cloete 1997:43).

Natural increase of the population as argued by Napier (1993:2) is another straining factor. The rate of natural increase is highest amongst the poorest communities, which means that the poor will constitute an ever-increasing proportion of the total urban population over the next decades (Napier 1993:22). According to Van Der Waldt and Du Toit (1997:380), issues arising from population growth are related to the capacity of South Africa's limited resources to provide for the peoples' needs and that it (population growth) has a ripple effect on the provision of services including housing.

In view of the foregoing, Phago (2010) stated that with the resources at the disposal of government and mindful of the continued high population growth rate and the rapid pace of urbanisation, it could take decades just to break this backlog.

\section{Migration}

The rapid expansion of cities throughout the world has been accompanied by equally rapid growth of informal settlements often known as slums (The University of Dublin Trinity College 2015). Slums develop as the formal housing market is unable to cater for the number of migrants, many of whom are extremely poor. South Africa fails to cope with housing demand set up by the massive influx into the country. The majority of migrants who infiltrate into the country either form informal settlements or add to the existing inhabitants of informal settlements. International Organization for Migration (2017) stated that South Africa is home to 4 million immigrants dominated by refugees and asylum seekers.
Emphatically, this suggests that migration of people to South Africa is not solely job seeking. Other reasons for migration into the city which are often regarded as potential 'pull' factors promoting in-migration to South Africa include infrastructure such as health facilities, medical services, education and social security.

\section{Urbanisation}

In general, the expansion of towns mirrors the broader national process of urbanisation (Bonner et al. 2012:117). Urbanisation is the change in the proportion of a population living in urban areas (Weeks 2012:357) or a social change on vast scale, which means deep and irrevocable changes that affect all sectors of society (Brutus 2002:3). Jiboye (2009:177) provided that urbanisation is the process of human agglomerations in multifunctional settlements of relatively substantial size. In this process a particular society shifts from being largely bound to the country to being bound by the city. Napier (1993:25) viewed it as a spontaneous phenomenon of in-migration to cities, which requires creative management. The process is irreversible once it has begun.

Urbanisation is accelerating at an exponential rate in developing countries and it has now become the modern trend of today's globalised world, which is making very rapid progress with the support of everyday innovative technology (Malik \& Wahid 2014). The unprecedented proliferation of slums and informal settlements and a chronic lack of adequate housing continue to be amongst the major challenges of urbanisation. Slums, informal settlements and inadequate housing remain the visible manifestations of poverty and inequality in cities. According to Raymond et al. (2011:21), available evidence shows that inadequate housing affects far more people in urban areas, despite being more acute in rural areas.

According to Statistics, South Africa's Household Survey (2017:111), South Africa has a much higher level of urbanisation than China (at 54\%), India (at 32\%) and Nigeria (at $47 \%$ ) and also that more than half of South Africa's population is urbanised - up to $64 \%$ of South Africans live in the country's urban centres.

In light of this discussion, urbanisation is one of the factors that have resulted in the unprecedented increase in the populace of South Africa's urban areas and is one of the contributors to housing delivery challenges in the country.

\section{The democratic government}

According to Section 26 of the South African Constitution of 1996, everyone has the right to adequate housing (Balkin \& Rhoden 2003:67). The state must take reasonable legislative and other measures within its available resources to achieve the progressive realisation of each of this right (Republic of South Africa 1996).

More than two decades after the present government assumed power, much of the South African society is still 
profoundly bifurcated and for hundreds of thousands of people, a place to call home remains an elusive dream (Lindsell 2007:81) despite the government's promises to free housing for all and also essential basic services (Jeffery 2010:351). In concurring with Jeffery's (2010:351) assertion, Bradley (2003:85) opined that the present government has to a certain extent contributed to the current inadequate housing challenges encountered by the country through its growth aligned policies.

Government's promises to free housing: The dawn of a democratic order in 1994 promised not only to finally end the discriminatory policies of apartheid but equally importantly to transform the lives of millions of oppressed South Africans (Bonner et al. 2012:198). Expectations were heightened by the fact that when the present government came into power (in 1994), one of the electoral promises it made was that it would endeavour to build a house for every South African (Bradley 2003:85). This is in line with ANC's (1994:23) emphasis that housing must be affordable to even the poorest of South Africans. However, Jeffery (2010:355) argued that the constant emphasis on the government's role in delivering free housing to the poor sapped an impetus to self-help and bred a strong dependency on the state. Following the heightened expectation, there was a massive mobility of people from rural areas and farms into towns where they awaited the delivery of free houses.

Government economic policies: Whilst several research studies (Barry 2003:2; Bonner et al. 2012:145; Cloete 1997:35; Eddy 2010:3; Malpass 1990:5) maintained that the present government is facing great difficulties and enormous backlogs because of the apartheid legacy to which they solely attribute the present housing delivery challenges, Brutus (2002:1) argued that the problems confronting many citizens are not simply the result of historical factors. The crisis of housing delivery and other basic services is actually a result of the pro-market (growth-oriented) policies adopted by the South African government since 1994, one of the primary goals of which was to reduce inflation and government spending to below $4 \%$ of the gross domestic product (GDP) thereby limiting the amount of money the government could spend on social needs including housing (Bradley 2003:85). According to Bond and Tait (1997:19), the housing situation was aggravated by systemic problems in the market-based housing provision systems exacerbating housing inequalities and resulting in inadequate housing. It is the view of Bonner et al. (2012:207) that from the mid-1990s, South Africa's economic policies were firmly framed within a neo-liberal paradigm, which as critics (Bond 2002; Bradley 2003; Datt 2002; Dyantyi 2010; Habitat \& ILO 1995; Harvey 2000; Khan \& Thring 2003; Knight 2002) pointed out is characterised by the expansion of opportunities and options for private capital accumulation. Habitat and ILO (1995:1) conceded by confirming that in many countries, it has been the policies adopted in response to macroeconomic trends rather than the trends themselves that have resulted in significant declines in shelter investment to a worsening of housing and infrastructure conditions.
Jeffery (2010:255) concurs with Bradley's (2003:85) argument that the present government has to a certain extent contributed to the current inadequate housing challenges encountered by the country through its growth aligned policies including the RDP - aimed at alleviating poverty and reconstructing the economy; GEAR - aimed at rebuilding and reshaping the economy in keeping with the goals of the RDP and ASGI-SA - aimed to help the state to attain its core objectives of halving poverty and unemployment by 2014, a target which was grossly missed.

Bhorat and Cassim (2004:21) agreed that since 1994, government introduced policies aimed primarily at creating an environment conducive to growth. May et al. (2004:18) and Mhone and Edigheji (2003:23) asserted that the GEAR economic strategy that was released by government in 1996 as a macroeconomic framework for growth and development resulted in reductions in the budget deficit and inflation against the backdrop of diminished expenditures in social votes including housing.

According to Jeffery (2010:239), whilst the RDP that had amongst its focus areas projects, which were aimed at meeting basic needs such as the construction of a million low-cost houses and the extension of electricity and piped water to people without them, government expenditure was not to be increased to meet the costs of the projects. African National Congress (1994:23) averred that one of RDP's first priorities was to provide for the homeless with housing - a human right. The resources used to finance the ASGI-SA strategy that was intended to help the state attain its core objectives of halving poverty and unemployment by 2014 also resulted in a decrease in funds intended for social needs, including housing (Jeffery 2010:88).

\section{Administrative issues}

Municipal maladministration, lack of control and corruption are the main administration-related factors that cause housing challenges and ultimately informal settlements. However, according to Harrison (2013), despite these factors, the African National Congress continues to mislead desperate Ekurhuleni Metropolitan Municipality (EMM) residents with promises of houses in order to win their votes.

Municipal maladministration: According to Robbins et al. (2008:20), it is hard to get high performance from public servants because they are generally lazy, more security oriented and less motivated. This is also applicable to EMM employees. Some them from departments that deal with the allocation of government houses have played a contributory role and continue to play a contributory role to the continuing housing delivery challenges encountered in EMM by being inefficient and ineffective (Jeffery 2010:239). Others aggravate the situation by involving themselves in corrupt activities that enrich themselves (Nathan 2013) at the expense of the metropolitan municipality as substantiated here. 


\section{Corruption}

According to Cloete and Mokgoro (1995:137), corruption is a particularly viral form of organisational cancer which once it enters the life stream of a public agency, quickly spreads to all parts - it is highly contagious, debilitating and costly to treat. Corruption also hinders delivery of affordable housing. According to Nathan (2013) because of the hierarchical character of the state and the related lack of accountability of high-level officials to their subordinates and the general public, 'shady' tender deals with private firms and outright theft of state funds and property is the norm.

Some government employees are involved in corrupt activities which lead to, amongst other variables, people not on housing waiting lists or people who do not qualify for government houses, like foreigners to be granted preference in the allocation of houses. Such conduct contradicts Cloete's (1997:69) assertion that every public official should display a sense of responsibility whilst performing official duties, in other words, the conduct should be above reproach. Corruption has become widespread, particularly in granting of housing subsidies, selection of building contractors and allocation of completed RDP houses (Jeffery 2010:354).

\section{Lack of control}

Control is strongly linked to accountability (Craythorne 1993:263). Lack of it leads to apathy, mismanagement and incompetence. According to Stoner, Freeman and Gilbert (1995:558), control is the process of ensuring that actual activities conform to planned activities. Van Der Waldt and Du Toit (1997:360) defined it as a process of monitoring activities to determine whether individual units and the institution itself are obtaining and using their resources efficiently to achieve their objectives. Du Toit, Erasmus and Strydom (2007:230) concurred and further maintained that control is applied to ensure that the organization's resources are deployed in such a way that the organisation reaches its goals and that if there is no control, the organization's resources could be wasted or misapplied. An organisation may formulate correct plans and policies but underperform or malperform because of a lack of necessary controls (Craythorne 1993:263). This is commonplace with South Africa.

\section{Economic variables}

Poverty, unemployment, affordability and poor access to housing finance are the general factors that, when combined, make up the economic variables. Whilst the private sector has been trying to service the populace that falls within its ambit with the construction and provision of houses, it is not sufficiently copying (Cloete 1997:69), leaving those that have not been serviced for one reason or other (e.g. not being legible because of having an unfavourable credit history, having been blacklisted or unable to afford) to increase the volumes that are dependable on government for the supply of adequate housing.
Poverty: A lack of access to adequate housing exposes one to the structural violence of poverty, its severity and associated complexities of despair and deprivation - relative or absolute - which constitute a significant threat to human security (Tshitereke 2008). It is undoubtedly true that in general the poor are inadequately housed and that the poorer a country is, the less adequate are housing conditions, at least in the low-income groups (Baloyi 2007:1) The South African society is largely characterised by extreme poverty (Steenekamp 2012:124), which is the leading social issue in the continuation of sprawling cities. The rate of natural increase is highest amongst the poorest communities, which means that the poor will constitute an ever-increasing proportion of the total urban population for many years to come (Napier 1993:22).

As Sokupa (2009:1) stated, government has the responsibility to make policies and laws about the rights and responsibilities of citizens and the delivery of government services. It collects revenue (income) from taxes which it is supposed to use to provide services and infrastructure that improve the lives of all the people in the country, particularly the poor. At present, millions of South Africans face severe problems in accessing even the most basic services and according to Sokupa (2009:1), many of these ultimately become matters of life and death, particularly with regard to issues of housing. More than 1 million families still live in shacks without power, often sharing a single tape and a mobile toilet amongst dozens of informal households (Steenekamp 2012). According to Gerber (2018), the housing backlog is presently 2.1 million.

In many areas of South Africa, where inadequate housing is befittingly synonymous with poverty (Ekurhuleni Metropolitan Municipality - IDP \& SDBIP 2015), the situation is worse with most of the inadequately housed, particularly shack dwellers being evicted by authorities and having their shacks and properties destroyed. They are forced to move to new areas where they face even more evictions. The poor are ignored by policymakers only to become the focus of public concern when they threaten property interests (Innes et al. 1992:165) or when general elections are around the corner. It is thus at moments of stress that the existence of the poor or urban homeless penetrates the public consciousness.

Affordability: Affordability refers to the relationship between income and house prices. Doshi and Ranganathan (2016:18) maintained that it (affordability) is one of the seven housing adequacy criteria based on the Office of the High Commissioner for Human Rights (OHCHR) definition on the right to adequate housing and observe that as affordability increasingly becomes a global crisis, with strong negative impact on the well-being of people and on the exacerbation of urban inequality, it has been selected as the most suitable measurement of adequacy of housing.

According to the 2017 Census, over 70\% of households in shacks in South Africa had a household income of less than R3500.00 per month, with 42\% earning less than 
R1000.00 per month (The Housing Development Agency 2018:25). Low incomes, particularly amongst the R2500.00 R7500.00 income group is the contributing factor to affordability (South Africa Survey 2008/9:582). This is in line with the assertion by the Provincial Budgets and Expenditure Review (2010:69) that in metropolitan areas, the house price to income ratio increased from a stable average of approximately 2.7 between 1996 and 2000 to 5.2 in 2005 (getting worse as the years progress), which substantiates the reality that housing has become less affordable.

These low incomes of large proportions of South Africa's population imply that many people are unable to afford adequate housing using their own financial resources alone (White Paper on Housing 1994:9). Fife (2007:36) concurred and maintained that it has become far more difficult for low-income earners to get onto the property ladder. Innes et al. (1992:181) propounded a view that socio-economic realities are such that even the most modest formal house is beyond the reach of the poor, the majority of whom live in informal shelters. Jeffery (2010:354) conceded in his statement that the minimum government housing subsidy has been eroded by building inflation and banks are not extending mortgage finance to the very poor who cannot afford even the cheapest and most rudimentary formal dwelling, which leaves informal settlements as their only alternative.

In light of the above, the Housing Delivery in South Africa (2014:2) stated that the housing sector was also affected by the 'unique phenomenon' of an increasing gap market. The gap market is made up of households earning too much to qualify for subsidised housing, just above R3500.00 a month, and too low to qualify for mortgage bonds, earning about R15 000.00.

Poor access to housing finance: Housing finance from financial institutions is key to the development of the primary and secondary housing market (Breaking New Ground 2004:4). One feature common to the poor is poor access to financial assistance in the form of loans for formal housing and serviced sites or housing subsidies by employers (Innes et al. 1992:179). Ward (2001:93) concurred in his statement that many poor families have no access to mortgages or loans for building or buying a home and observed that lack of access to credit forces families to make do with inadequate resources, to live and work in multifunctional spaces combining makeshift shacks, partly finished rooms and temporary partitions for walls. Banks have previously been reluctant to invest in townships or new low-cost housing developments mainly because of negative perceptions about crime and repayment risks (Bradley 2003:85). Datta and Jones (1999:7) observed that one of the reasons why families with inadequate shelter are unable to access loans is that they work in the informal sector and so are less able to provide employment documentation whether or not their current income level would qualify them for a loan. Research shows that financing institutions favour households with above average incomes, employed in the formal sector, and where the head of household is male (Ward 2001:93). Even housing finance institutions aimed at assisting low-income families have often been inaccessible to the majority of the poor (Datta \& Jones 1999:7). The Home Loan disclosure Act that was designed to allow the government to monitor trends within banks was drawn up in response to claims that banks have, in the past been treating blacks and low-income earners with prejudice (Bradley 2003:85). With the housing market currently being driven by first-time buyers and the average house price increasing by $3.2 \%$ month-on-month to R665 167.00 (South Africa Year Book 2017/18:347), the number of people migrating into informal settlements is set to further plummet.

\section{Housing shortage}

Research suggests that constraints in housing supply may be another cause of inadequate shelter particularly for the poor (Duncan 2008:9). In the same light, Bradley (2003:83) highlighted that at the centre of the housing inadequacy problem is a drastic shortage of housing. Housing shortage means that the total number of households exceeds the number of dwellings available (Malpass 1990:5). The shortage of housing in South Africa is also attributed to the unavailability of land. Efficient assembly and release of appropriately located land for housing is critical to achieving the desired rate of delivery of housing (White Paper on Housing 1994:27) to arrest the problem of housing inadequacy.

Inadequate housing can be manifested in many forms that may appear individually or in combination and may be regarded locally as a problem or may not be (Harvey 2000:28). Crowding or inadequacy of space either in terms of area or in the number of separate rooms is a common sign of inadequate housing (Habitat \& ILO 1995:2).

\section{Unavailability of land}

Angel (2000:192) articulated the importance of access to land in providing for adequate housing as follows: 'The first essential condition for a vibrant and well-functioning housing sector is the availability of residential land, in ample supply and at affordable prices'. According to the Minister of Human Settlements, Nomaindiya Mfeketo, land continues to be 'one of the major problems hindering the delivery of sustainable human settlements in our country' (Gerber 2018). Slow and complex land identification, allocation and development processes resulted in insufficient land for housing development purposes (Housing Delivery in South Africa 2014:2).

In addition, a study by Harvard's Center for Urban DevelopmentStudies (2000) explained the land phenomenon as follows:

State ownership of land in and around cities is limited. For the majority of the population, access to land is limited to two equally undesirable options, settlement on marginal sites or invasion of public or privately owned land. Topography and soil conditions constrain the availability of buildable land, inflating land values and pushing poorer segments of the population to settle on marginal and environmentally hazardous sites such as steep slopes or lowlands, while pressure on 
accessible sites has led to overcrowding and congestion in existing settlements. (p. 91)

According to Duncan (2008:9), some of the causes of scarcity of residential land are as follows:

- reluctance by governments to confront concentrated landownership

- rampant land speculation

- failure of central governments to regulate land markets and failure of municipal governments to provide workable urban development strategies

- legal impediments such as laws that only support regularisation of squatter settlements on publicly held land, but not on private land and laws that require servicing of plots prior to issuing titles.

Dyantyi (2010:80) concurred that unavailability of land is the biggest housing delivery constraint in South Africa. Whilst the Housing Development Agency (HDA) is intended to help with the acquisition and release of land, as well as the provision of funding and the unblocking of delivery constraints and it will also seek to make a wider range of housing choices available including affordable, well-located rental housing (Jeffery 2010:354), the unavailability of land poses a major insurmountable challenge (City of Ekurhuleni 2011:25).

Ajayi (2012:18-19) agreed with the above causes of inadequate housing in his observation that in spite of the efforts of the South African Government in the provision of adequate housing since 1994, the housing sector is still beset with the following challenges:

- lack of capacity to deliver as a result of government's inability to develop workable policies because of inadequate funding

- poor data collection systems and monitoring

- the difficulties of national policy and provincial allocations to respond to the changing nature of demand occasioned by increased urbanisation and demographic pressure

- high expectations of the communities

- lack of communication with communities by the government

- contractors' inability to deliver adequately

- decreases in the overall national housing expenditure (R10bn budget cut for human settlements over the medium term period [2018] whilst the housing backlog stands at an estimated 2.1 million [Gerber 2018]).

- little attention given by the government to non-subsidised efforts

- lack of capacity particularly in the municipalities occasioned by a crisis of human capital development

- lack of availability of well-located land

- government restructuring of urban policy rather than decentralisation, which would have increased economic efficiency and political accountability and by extension, a reduction in poverty

- the extent and high rate of urbanisation resulted in the proliferation of informal settlements and unplanned periurban growth
- pre-democratic legacies and inequalities persist resulting in the continuous unequal quality of services, housing and the urban environment

- neoliberal macroeconomic policies such as the introduction of the GEAR programme that has further created marginalisation and poverty with attendant high unemployment rate

- absence of sustainability linkages that should have aided the economic multiplier of housing

- decline in the value of the subsidy in addition to the increase in the input costs of contractors

- the inability of the social housing programme to deliver at scale

- non creation of satisfactory integrated housing environments

- the withdrawal of the large construction groups from the low-income market

- high land costs in advantageous locations

- differences in the interpretation and application of the housing policy

- high building costs in areas where land is more affordable but geological and topographical conditions are not ideal

- limited participation from the financial sector in the financing of low-income housing

- significant under-spending on budget for low-income housing by responsible housing departments brought about as a result of capacity shortages, especially at the municipal level

- the identification, acquisition, assembly and release of state-owned and private land in terms of the revised procurement framework have proved to be a slow and complex process.

All the foregoing are fundamental bottlenecks in the road to providing sustainable and adequate housing. They are symptomatic of and are inextricably linked to inadequate housing and its ramifications.

\section{Ramifications of housing inadequacy in South Africa}

As a result of housing inadequacy, living conditions within the settlements in which inadequate housing is rife are typically poor with residents facing a range of basic livelihood challenges, including poor access to basic sanitation and water supply, solid waste accumulation, recurrent shack fires, safety and security risks, and a range of health hazards Misselhorn (2010).

This study maintains that the ramifications of housing inadequacy include the following:

- protests

- informal settlements

- health challenges

- shack fires

- flooding

- violence and criminality

- corruption

- xenophobic attacks 


\section{Protests}

According to Lonakimidis and Dominelli (2016:437), a new thinking, which has dominated many spaces of discourse in South Africa on the need for radical change and transformation, points to the people who have become both worn down and weary as a result of decades of unfulfilled promises and pledges regarding their own fundamental human rights and needs, particularly with respect to housing. This radical change in thinking stems partly from the recognition of the fact that without housing which is of sufficient quality, there is an ever-increasing probability of rendering vast segments of previously disadvantaged population groups completely powerless and incapable of participating in decision-making. Rather than finally taking their rightful place in a liberated society after the privations that they had endured under a dispensation which is now internationally recognised as having been a criminal one, these citizens stand to be subjected to further humiliation and loss of dignity (Young 2004). It is in this light that housing inadequacy incense the inadequately housed to take to the streets in violent protests where property is damaged and lives are lost as a way of seeking attention from the government and demanding promises made to them of the delivery of free adequate housing to be met.

\section{Informal settlements}

As a result of the critical lack of affordable housing many poor and low-income households have had to resort to living in South Africa's growing informal settlements. As provided in South Africa's National Housing Code, informal settlements are typically identified on the basis of the following characteristics: illegality and informality, inappropriate locations, restricted public and private sector investment, poverty and vulnerability and social stress (Statistics South Africa's Household Survey 2017).

Informal settlements are a clear depiction of inadequate shelter. According to The University of Dublin, Trinity College (2015), informal settlements are living conditions (shacks, squatter camps, slums) which lack at least one of the basic conditions of basic housing, namely adequate sanitation, improved water supply, durable housing or adequate living space. The issue of informal settlements has plagued South Africa since the end of apartheid, when many black Africans relocated to large cities in search of a new life with better employment opportunities (Phago 2010). Gilbert (2004) concurred in his statement that insufficient and inadequate housing for the urban poor has a long history in South Africa, with apartheid-era policies of urban containment resulting in overcrowded and under-serviced townships and informal settlements on the urban periphery.

Whilst Shaw (2003:405) stated that information on the number of people living in informal settlements is often limited because inhabitants are often only inadequately covered by formal censuses and that census data may therefore not provide a clear separation of those living in informal settlements, statistics indicate that in 2016, approximately one in seven households in South Africa lived in informal dwellings (this figure is higher in metropolitan areas, where one in every five households lived in an informal dwelling) moreover, the HDA has noted that these figures are likely to under-represent the real growth in informal settlements (Statistics South Africa's Household Survey 2017).

In supporting these statistics, Misselhorn (2010) provided that at least $10 \%$ of South Africa's 44 million people live in urban informal settlements. This equates to more than 1.2 million households and an informal settlement population of over 4.4 million. Approximately $23 \%$ of the households in South Africa's nine largest cities are estimated to be without adequate shelter (Misselhorn 2010). In reality, the actual numbers are probably significantly higher than these figures suggest.

\section{Health challenges}

The relationship between inadequate housing and health is multifaceted. A healthy home needs to have sound structure, to be free of hazards, to provide adequate facilities for sleeping, personal hygiene, the preparation and storage of food and an environment for comfortable relaxation, for privacy and peace and to provide the facility for social exchange with friends, family and others (Wilkinson, Close \& Crabbe 2016). The local environment is also important in determining such factors as fear of crime, access to local services and facilities and in promoting social interaction. Housing is therefore an important determinant of health.

Inadequate housing affects health through both direct and indirect ways. Direct influences include the effect of the material conditions of housing on physical health and the effect of the associated social conditions on mental health and well-being. Inadequate housing has an indirect influence on health, at both the individual and neighbourhood or group level, by being an important component of general socioeconomic status and influencing access to services (Shaw 2003:408). The interrelationships between these mechanisms mean that they operate together, and that they are generally associated with other negative social and economic influences as depicted in Figure 1.

Substandard (inadequate) housing is a major public health issue. In agreement with this, Bonnefoy (2007:411) stated that for many years, the housing environment has been acknowledged as one of the main settings that affect human health. This is also in line with Jackson's (2003) view that living and housing conditions are the basis of many factors influencing residential health. Epidemiological findings suggest strong associations between housing conditions and health effects - the relevance of housing conditions as a key factor influencing mental health, sleep quality, indoor air, home safety, accessibility, obesity, mould growth, hydrothermal conditions and energy consumption, perception of crime and inadequate housing (Bonnefoy's 2007:411). 


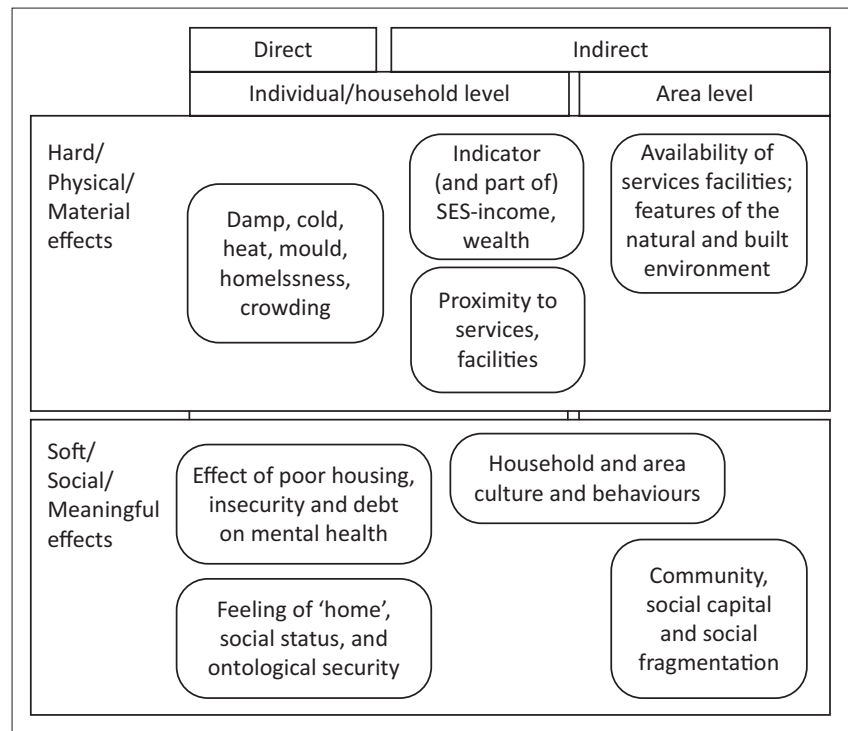

Source: Shaw, M., 2003, Housing and public health, Department of Social Medicine, University of Bristol, Bristol.

FIGURE 1: Direct and indirect ways in which housing can affect health.

Wilkinson et al. (2016) posited that the health problems faced by communities of inadequate housing can be broadly grouped into three interrelated categories:

- infectious diseases

- problems resulting from social disruption and despair

- 'lifestyle-related' diseases resulting from poor nutrition, lack of exercise and emotional stress.

The quality of housing impacts on all these three categories. Infectious diseases have the greatest impact on residents of inadequate housing, particularly some informal settlements and are directly related to factors such as inadequate water supplies, washing facilities, sanitation and overcrowding.

Bhandari and Wagner (2006) pinpoints the following as the nine 'Healthy Living Practices' and state that the lack of any one or more of them is/are the ramifications of housing inadequacy:

- Washing people

- Washing clothes and bedding

- Removing waste safely

- Improving nutrition: the ability to store, prepare and cook food

- Reducing crowding

- Reducing negative contact between people and animals, insects and vermin

- Reducing dust

- Controlling the temperature of the living environment

- Reducing trauma

The effective and safe removal of human waste and the provision of an adequate and safe water supply for washing, drinking and cooking have long been recognised as essential to health and have been key factors in improvements in health in developed countries. Five of the nine healthy living practices are to some extent dependent on water supply. Water supplies are deficient in many communities of inadequate housing where households lack adequate facilities for washing people and clothes. Sewerage infrastructure is also inadequate or non-existent and where it exists, it is subject to frequent breakdown and leakages. These factors are barriers to good domestic hygiene, including hand washing with soap and toilet training of young children. Failure to dispose safely of human faeces contributes to high rates of gastroenteritis and parasitic conditions, which are in turn also important factors in malnutrition and decreased resistance to infection.

Structural deficiencies present risk of injury and exposure to heat, cold, dust and insects. These exposures increase risks of heart, respiratory, eye and insect-borne diseases and skin infections. Structural deficiencies may also limit privacy, interfere with personal hygiene behaviours and increase social stresses, all of which may have a variety of consequences for health and well-being. The lack of reliable and safe power supplies is also a barrier to good health through a number of ways - exposure to excessive cold or heat, and lack of hot water for washing, a safe fuel source for cooking and good lighting for a range of domestic activities, including studying.

In inadequate housing set-ups, community power supplies are subject to relatively frequent interruptions, and the use of power by many households is limited by lack of funds for purchasing electricity. Illegal power connections are also rife. These kill residents through electric shocks and at times burn down shelters resulting in loss of life and property.

Bonnefoy (2007) agreed that the quality of housing conditions plays a decisive role in the health status of the residents. Many health problems are either directly or indirectly related to the building itself, because of the construction materials that were used and the equipment installed or the size or design of the individual dwellings. According to Austin, Furr and Spine (2002:419), studies on housing and health have singled out features of the housing environment that pose serious direct or indirect threats to the physical and mental health of people. The most important of these are overcrowding, location, tenure and housing conditions (UN-Habitat 2014). Researchers have pointed out that a high level of household crowding can produce stress leading to illness and that congestion ensures easy transmission of communicable diseases (Austin et al. 2002:425; Wilkinson, Armstrong \& Landon 2001:24).

Representing the spatial point of reference for each individual, the home also has a broad influence on the psychosocial and mental well-being by providing the basis for place attachment and identity as well as a last refuge from daily life. The invasion of the home by harmful insects and pests is a direct threat to health, as pests can function as carrier of pathogens, diverse diseases and allergens (Bonnefoy 2007). Inadequate, poor quality housing, providing insufficient protection from the outside, from noise, from scrutiny, and intrusion can be the source of major suffering. Such events may generate 
pathological manifestations such as anxiety, depression, insomnia, paranoid feelings and social dysfunction (Austin et al. 2002:421). Bad circumstances in neighbourhood relations generate social pathologies: aggressiveness, violence, vandalism, depression, anxiety, somatic complaints and even paranoid feelings and ideas (Wilkinson et al. 2001).

According to Shaw (2003:402), in extreme conditions, inadequate housing is seen to be related to cases of hypothermia and in certain populations severe overcrowding has been related to the prevalence of tuberculosis. She (Shaw 2003:403) further stated that homes that are damp, which can often result from condensation because of inadequate ventilation, allow the growth of mould, fungi and other microorganisms. Dampness and mould have been found to be associated with the symptoms of wheezing, aches and pains, 'nerves', diarrhoea, headaches and fever and children are particularly affected.

Austin et al. (2002:420) stated that there is increasing evidence that mould growth in damp shelters is an important risk factor for respiratory illnesses. Mould-related symptoms are likely as a result of irritations of the throat and eyes, allergies (most frequently allergic rhinitis), lower respiratory symptoms (dry or productive cough, wheeze), and asthma, as well as increased incidence of respiratory infections (Bonnefoy 2007).

\section{Shack fires}

Inadequate shelter, leaves residents open to the possibility of fires particularly in informal settlements that claim lives in South Africa each year. The prevalence of fire is related to the materials used to construct the home, the maintenance of the building (and equipment such as heating devices and whether or not they are functional) and the behaviours (whether people smoke, use deep fat fryers, leave candles, stoves and fires unattended) and emergency responses of the inhabitants. Illegal electrical connections particularly to backyard shacks that are made of flimsy materials as previously stated posed increased fire risks. Injuries as a general category and injuries and deaths because of house fires specifically have been found to have steep gradients according to socioeconomic position, such that those who are more disadvantaged are more likely to come to harm (Shaw 2003:406). In this category, some of the deaths occur through poisoning by carbon monoxide from the smoke.

\section{Flooding}

Adequate housing protects people against floods and associated stagnant water, in which mosquitoes and other insects breed, which is the key factor in spreading infectious diseases (Tshitereke 2008). The flooding ramifications of inadequate housing are often underestimated because they are seasonal. However, the effect of flooding can be severe on communities particularly in areas with no drainage systems. These include:
- damage of furniture and important documentation such as identity documents and certificates

- levels of biological contamination, often through contamination with sewage

- water pollution from industrial waste (e.g. chemicals and acids) and also dead animals and domestic garbage

- disrupted access to services, for example, transport, community services, schools, health services, postal deliveries, etc.

- increased risk of infectious diseases, especially water borne, for example, cholera, gastrointestinal diseases and from overcrowding and lack of fresh water supplies.

\section{Violence and criminality}

Another potential negative impact of inadequate housing that is often overlooked in reviews on this subject is that of domestic violence (Shaw 2003:410). This seems to suggest that a home is not always a refuge from the outside world: it can be a source of strain and danger, especially for women and children. To them the home can be the primary location of physical, emotional and sexual abuse and also a prison (Shaw 2003:410).

Common explanations for neighbourhood violence and criminality point simplistically to poverty and social disorganisation as causes, which are a common feature of inadequate housing (Gorman et al. 2001). This is the case in South Africa as well as in other urban areas across the globe. More nuanced explanations draw attention to subtle considerations of social cohesion, distrust and weakened informal control in urban communities Lipton and Gruenewald (2002). According to the 'collective efficacy' theory high levels of violence and violent crime are prevalent in communities that face challenges of concentrated disadvantage in terms of poverty, high unemployment and a considerable alcohol and drug abuse burden as is the case in inadequate housing areas (Gorman et al. 2001).

As Huchzermeyer (2011) puts it, smaller houses (sometimes informal) lead to greater tensions between couples, which could lead to violence relating them to the Brazilian context. Caldeira (2000:79) explained about inadequate houses: 'Excluded from the universe of the proper, they are symbolically constituted as spaces of crime, spaces of anomalous, polluting, and dangerous qualities'. She further argues that the inhabitants of such spaces are also conceived of as marginal with the list of prejudices against them endless. This criminalisation shapes the notion that inadequate housing areas particularly informal settlements are spaces of crime and according to Meth (2016), it is commonly alleged that an anti-establishment or oppositional, culture prevails in slum areas, which is broadly supportive of all kinds of illegal activities.

Bauer (2010:4) argued that when a large population group in cities is afflicted by social exclusion and discrimination, ill health, poor conditions, as well as restricted access to land and basic infrastructure, increasing levels of criminal 
violence, lack of safety and general fear in the use of public space are often observed. This is synonymous with communities in inadequate housing areas.

\section{Corruption}

Some societies are trapped in a high-corruption equilibrium, or, to put it differently, are pervasively corrupt (Ledeneva \& Kurkchiyan 2000:99). The corruption discourse upends mainstream development agendas that narrowly equate corruption with individual acts of bribery and the longstanding notion that corruption manifests mainly amongst the poor and lower rungs of the state.

Corruption, like many other forms of behaviour when placed under the scrutiny of the social science lens, proves to be an elusive and complex phenomenon: in fact the more one examines it the more difficult it becomes to separate corruption from other forms of social exchange (Doshi \& Ranganathan 2016:18). According to Andreski (1968:92), the task of definition is not made easier by the fact that corruption, by its very nature, is inseparable from questions of public morality and morality in general. This as Harvey (2000:15) puts it, has sometimes excited a tendency to condemn which has impeded objective analysis. In light of this, an attempt at definition should be made not simply out of the primordial academic need to demarcate, to classify or to pigeon-hole, but because, as Ledeneva and Kurkchiyan (2000:100) suggested, the enterprise itself helps to tease out the essential characteristics of the phenomenon under discussion.

Various authors offer different definitions of corruption as follows:

- Corruption is the behaviour of public officials which deviates from accepted norms in order to serve private ends (Carter 1990:5)

- Corruption is behaviour which deviates from the formal duties of a public role because of private-interests regarding (personal, close family, private clique) pecuniary or status gains; or violates rules against the exercise of certain types of private-regarding influence (Harvey 2000:15)

- Corruption is the misuse of public power for private profit (Harvey 2000)

- The practice of using the power of public office for making private gain in breach of laws and regulations nominally in force (Andreski 1968:92)

- Corruption is the abuse of official powers for personal gain (Ayres 1998).

It is clear that all the above definitions depend upon the existence of a public domain which is recognisably separate from the private sphere. In exploring the pervasiveness of these definitions along the housing lines, Yuen (2002) argued that they (definitions) may reflect a range of factors, including the opacity, clumsiness and arbitrariness of the housing problems.
Doshi and Ranganathan (2016:20) argued that 'corruption' serves as a cultural, semantic and moral rubric that expresses and shapes a sense of structural injustice in the moment of sharpening urban inequality. With regard to inadequate housing, corruption is both a cause and an effect (Austin et al. 2002). It (inadequate housing) both breeds and is bred by corruption. Housing officials and people with connections with influential people in the housing department take advantage of community members who are inadequately housed or foreigners and promise them houses and also to push their names forward on housing waiting lists at a fee. A significant challenge comes from the media, intellectuals and the youth, who assert their disgust with corruption, materialism and bureaucratic inefficiency (Austin et al. 2002). This results in revolts and protests some of which are extremely rambunctious, which substantiates Yuen's (2002) view that the corruption discourse is repurposed in disruptive ways. According to Matunhu (2008:104), corruption exacerbates poverty and xenophobia.

The impact of corruption extends beyond the specific actions of the perpetrators. The overt result of the practice is unfinished roads, housing inadequacy, political and social turmoil, crumbling schools and crippled health systems (Matunhu 2008:104). These negatives culminate into a depressed community. The sum effect of corruption is that it compromises social and economic development of a nation, which may bring about disgruntlement by the civil society (Matunhu 2008:105).

\section{Xenophobic attacks}

South Africa is torn between the persistence of an exclusionary socioeconomic structure marked by deep poverty and extreme inequality on the one hand and on the other hand the symbolic and institutional rupture of mobilisation of collective violence in the form of xenophobia.

Xenophobic attacks are attacks of foreigners by the citizens of a country because of the abnormal fear or envy or hatred of them (Agus et al. 2002). Such attacks can be at a particular point in time and either occur throughout the whole of a country or at just a section or sections of it. In South Africa, foreigners are blamed for causing a plethora of problems including the shortage and inadequacy of housing. Foreigners are blamed for almost every social ill and problem in South Africa. Both the government and the main opposition party want to build higher fences at the border to prevent foreigners from coming in and undermining South Africa's security and prosperity (Matunhu 2008:99). Politicians claim that foreigners are the main reason for high crime rates; immigrants are blamed for the hardships experienced by millions of poor South Africans and for overrunning and taking over South Africa's cities (Eddy 2010:3).

A common theme by locals is the allegation that foreigners buy fake identity documents and corrupt housing authorities to get them to be prioritised on housing waiting lists over locals who would have been on the lists for several years. 
It is alleged that they (foreigners) get better housing opportunities than the locals. This triggers anger in South Africans, which results in foreigners being attacked and forced to go back to their countries.

It is the poor who cannot afford to either purchase or construct houses in designated suburbs who turn to areas of inadequate housing including squatter camps/informal settlement like Alexandria (Matunhu 2008:99). As the population of the poor increases naturally and as a result of the continuous stream of immigrants feeding into the economy, the struggle for survival becomes more difficult whilst the competition for scarce resources and opportunities becomes fiercer.

The xenophobic discourse serves not only to reassure identity when nationalistic self-images run into crisis but is an element of a political struggle about who has the right to be cared for by the state and society: a fight for the collective goods of the modern state (Wimmer 1997:10). However, he (Wimmer 1997:10) then goes on to contradict this statement by asserting that xenophobic views of the social world are not instrumental to a fight for scarce jobs or housing and arguing that they are not mere radicalisations of the discourse of exclusion and devaluation which political and administrative elites generate and institutionalise, for example, in immigration policies.

The influx of foreigners (both legal and illegal) from drought stricken and strife torn nations in other parts of sub-Saharan Africa disproportionately compounds the housing problem in South Africa, with the majority of them driven by better job prospects. Eddy (2010:3) agreed that the phenomenon of territorial human mobility continued to place a greater strain on services, which led to higher proportions of people living in informal settlements.

Matunhu (2008:105) maintained that xenophobic attacks lead to the destruction of property that belonged to foreigners, for instance in the Alexandra xenophobic attacks of 2008, stores and tuck shops that belonged to migrants were looted and destroyed causing psychological trauma to the survivors. Because of their prevalence, the violent attacks on foreigners in South Africa are widespread and intense, becoming inherently more chaotic, normalised and pervasive, reaching insurrectionary proportions in some cases.

\section{Findings}

The findings of this article suggest that inadequate housing continues to be a serious political, social and economic problem in South Africa and that most strikingly, the deficit in adequate housing continues to grow each year, forcing more families to live in dangerous or squalid shelter conditions. The findings further suggest that protests, informal settlements, health challenges, shack fires, flooding, violence and criminality, corruption and xenophobic attacks are the ramifications of housing inadequacy in South Africa.

\section{Recommendations}

In order to adequately address the inadequate housing challenges in South Africa, this article recommends that the idea of housing must be understood not for what it is (a physical product), but for what it does (a process) and also for a change in housing policies, which include an appropriate multidimensional strategy and an ample menu of targeted interventions that are premised on a resolute commitment of resources. Further, through the HDA, an entity of the Department of Human Settlements, the government needs to engage the private sector, state-owned enterprises, provinces and municipalities to unlock strategic parcels of land suitable for human settlements development, which provision, especially for low-income groups should be at subsidised rates. The country needs an efficient, formidable and incorruptible department that is able to perform the huge task of spatial integration.

\section{Conclusion}

Housing is a central component of productive, healthy and meaningful lives and a principal social determinant of health and well-being. Inadequate housing continues to be a serious political, social and economic problem in South Africa. Most strikingly, the deficit in adequate housing continues to grow each year, forcing more families, particularly the poor and low-income urban groups to live in dangerous or squalid shelter conditions. This is particularly true with regard to the necessary supporting infrastructure, especially sanitation, clean water, toilet facilities and sewerage. Population growth and particularly the increase in urban areas caused by natural population growth and the exodus from the rural areas and other African countries continue to make the South African housing situation worse. Other causes of inadequate housing are historical issues pertaining to the apartheid government, government economic policies, economic variables, housing shortage and unavailability of land. This (inadequate housing) results in protests, informal settlements, health challenges, shack fires, violence and criminality, corruption and xenophobic attacks.

\section{Acknowledgements}

This article is a follow-up of the previously published work - Obstacles to Housing Delivery in Ekurhuleni Metropolitan Municipality: A Critical Review of Output and Input, published in Africa's Public Service Delivery and Performance Review (APSDPR), Volume 3 Issue 4, 2015, Causes of informal settlements in Ekurhuleni Metropolitan Municipality: An exploration, published in APSDPR Volume 5 Issue 1, 2017 and Government contribution to housing delivery challenges in EMM currently under review at APSDPR. 


\section{Competing interests}

The author declares that he has no financial or personal relationships, which may have inappropriately influenced him in writing this article.

\section{Author's contributions}

I declare that I am the sole author of this research article.

\section{Ethical consideration}

This article followed all ethical standards for carrying out research.

\section{Funding information}

This research received no specific grant from any funding agency in the public, commercial or not-for-profit sectors.

\section{Data availability}

Data sharing is not applicable to this article as no new data were created or analysed in this study

\section{Disclaimer}

The views and opinions expressed in this article are those of the authors and do not necessarily reflect the official policy or position of any affiliated agency of the authors.

\section{References}

Ademiluyi, I.A., 2010, 'Public housing delivery strategies in Nigeria: A historical perspective of policies and programmes', Journal of sustainable development in Africa 12(6), June.

African National Congress (ANC), 1994, Reconstruction and Development Programme (RDP): A policy framework, p. 23, Umanyano Publications, Johannesburg.

Agus, M.R., Doling, J. \& Lee, D.S., 2002, Housing policy systems in South and East Asia McMillan, Palgrave.

Ajayi, J.R., 2012, 'Strategies for sustainable housing cooperatives in South Africa', Unpublished Philosophiae Doctor thesis, Nelson Mandela Metropolitan University, Accra.

Andreski, S., 1968, The African predicament, Science and Society, 34(3), 366-368.

Angel, S., 2000, Housing policy matters: A global analysis, Oxford University Press, Oxford.

Arku, G. \& Harris, R., 2005, 'Housing as a tool of economic development since 1929', International Journal of Urban and Regional Research 29(4), 895-915. https://doi. org/10.1111/j.1468-2427.2005.00627.x

Austin, D.M., Furr, L.A. \& Spine, M., 2002, 'The effects of neighbourhood conditions on perceptions of Safety', Crime and violence as development issues in Latin America and the Caribbean, World Bank, Washington, DC.

Ayres, S., 1998, The African predicament, University of California Press, Berkeley, CA.

Balkin, P. \& Rhoden, M., 2003, Housing policy: An introduction, 4th edn., Routledge, New York, NY.

Barry, M., 2003, 'Peri-urban tenure management in South Africa', Marrakeck 2(5), 1-14.

Bauer, B., 2010, Violence prevention through urban upgrading: Experience from financial cooperation Germany, German Federal Ministry for Economic Cooperation and Development (BMZ), Government Printer, Frankfurt.

Bhandari, A. \& Wagner, T., 2006, 'Self-reported utilization of health care services: Improving measurement and accuracy', Medical Care Research and Review 63(2), 217-235. https://doi.org/10.1177/1077558705285298

Bhorat, H. \& Cassim, R., 2004, 'How can the South African Engine become a Ferrari?', Special Report 28(2), 121-124.

Bond, P., 2002, Unsustainable South Africa - Environment, development and socia protest, Merlin Press, London.

Bond, P. \& Tait, A., 1997, 'The failure of housing policy in post-apartheid South Africa', Urban Forum 8, 19-41. https://doi.org/10.1007/BF03036607

Bonnefoy, X., 2007, 'Inadequate housing and health: an overview', International Journal of Environment and Pollution 30(3), 411-429. https://doi.org/10.1504/ IJEP.2007.014819
Bonner, P. Nieftagodien, N. \& Mathabatha, S., 2012, Ekurhuleni - The making of an urban region, Wits University Press, Johannesburg.

Bradley, G., 2003, 'Housing', Black Business Quarterly 6(3) 17.

Breaking New Ground, 2004, 'A comprehensive plan for the development of sustainable human settlements', viewed n.d., from http://www.dhs.gov.za/sites/ default/files/documents/26082014_BNG2004.pdf.

Brutus, D., 2002, Cost recovery and the crisis of service delivery in South Africa, Human Sciences Research Council Publishers, Cape Town.

Caldeira, T., 2000, City of walls: Crime, segregation, and citizenship in São Paolo, University of California Press, Berkeley, CA.

Carrington, D., 2015, World population to hit $11 \mathrm{bn}$ in 2100 - with $70 \%$ chance of continuous rise, viewed 27 November 2015, from http://www.geohive.com/ earth/population_now.aspx

Carter, R., 1990, Urban and rural settlements, Longman Group United Kingdom Limited, Harlow.

Chen, M., Sebstad, J. \& O'Connell, L., 1999, 'Counting the invisible workforce: The case of homebased workers', World Development 27(3), 603-610. https://doi. org/10.1016/S0305-750X(98)00154-5

City of Ekurhuleni, 2011, City of Ekurhuleni Annual Report 2010-2011: EMM human settlements, pp. 7-25, City of Ekurhuleni, Germiston.

Cloete, F., 1997, Local government transformation in South Africa, J.L. Van Schaik Publishers, Pretoria.

Cloete, F. \& Mokgoro, J., 1995, Policies for public service transformation, Juta and Company Limited, Cape Town.

Craythorne, D.L., 1993, Municipal administration, 3rd edn., Juta and company limited, Cape Town.

Datt, R., 2002, The human development and economic development, Deep and Deep Publications (Pvt) Ltd., New Delhi.

Datta, K. \& Jones, G.A., 1998, Housing and finance in developing countries, Routledge Studies in Development and Society, Routledge, London.

Doshi, S. \& Ranganathan, M., 2016, 'Contesting the unethical city: Land dispossession and corruption narratives in urban India', Annals of the American Association of Geographers 107(1), 18-20. https://doi.org/10.1080/24694452.2016.1226124

Du Toit, G.S., Erasmus, B.J. \& Strydom, J.W., 2007, Introduction to Business Management, 7th edn., Oxford University Press, Cape Town.

Duncan, J., 2008, Causes of inadequate housing in Latin America and the Caribbean Habitat for Humanity Latin America \& the Caribbean, New York, NY.

Dyantyi, Q.R., 2007, 'A place to call home', Black Business Quarterly, p. 71, BBQ Publishing, Johannesburg.

Eddy, G., 2010, 'Fast facts - South African Institute of race relations', Economic Growth and Education are the Keys 9(1), 6

Ekurhuleni Metropolitan Municipality, 2015, Integrated development plan and SDBIP service delivery budget implementation plan, City of Ekurhuleni, Germiston.

Fife, I., 2007, 'Property inequality - Entry denied', Financial Mail - Business Live 192(9), August 24.

Gerber, J., 2018, 'R10bn budget slash for Human Settlements Department', City Press, 10 May, p. 53

Giddings, S.W., 2007, Housing challenges and opportunities in Sub Saharan Africa, International housing coalition, Washington.

Gilbert, A., 2004, 'Helping the poor through housing subsidies: Lessons from Chile, Colombia and South Africa', Habitat International 28(1), 13-40. https://doi. org/10.1016/S0197-3975(02)00070-X

Gorman, D.M., Speer, P.W., Gruenewald, P.J. \& Labouvie, E.W., 2001, 'Spatial dynamics of alcohol availability, neighbourhood structure and violent crime', Journal of Studies on Alcohol 62(1), 628-636. https://doi.org/10.15288/jsa.2001.62.628

Gunter, A. \& Manuel, K., 2016, 'A role for housing in development: using housing as a catalyst for development in South Africa', Local Economy: The Journal of the Local Economy Policy Unit 31(1-2), 312-321. https://doi. org/10.1177/0269094215624352

Harrison, B., 2013, 'No hope for Ekurhuleni's Housing backlog', Germiston City News, 18 July, Germiston.

Harvard's Center for Urban Development Studies, 2000, The Harvard Crimson Newspaper, 27 July 2000, Cambridge, p. 91.

Harvey, J., 2000, Urban land economies, 5th edn., Palgrave Publishers, New York, NY.

Henning, E., 2004, Finding your way in Qualitative Research, Van Schaik Publishers, Pretoria.

Housing Delivery in South Africa, 2014, Fuller housing centre report, draft report: Housing delivery, The Fuller Centre for Housing, Cape Town.

Huchzermeyer, M., 2011, Cities with 'Slums': From informal settlement eradication to a right to the city in Africa, UCT Press, Johannesburg.

Innes, D., Kentridge, M. \& Perold, H., 1992, Power and profit - Politics, labour and business in South Africa, Oxford University Press, Cape Town.

International Organization for Migration, 2017, Regional strategy for Southern Africa, Pretoria.

Jackson, A., 2003, Hovels to high rise - State housing in Europe since 1850, Routledge Publishers, London.

Jeffery, A. 2010, Chasing the rainbow: South Africa's move from Mandela to Zuma, Art Publishers, Cape Town.

Jiboye, A.D. 2009, 'The challenges of sustainable housing and urban development in Nigeria', Journal of Environmental Research and Policies 4(3), 23-27. 
Khan, F. \& Thring, P., 2003, Housing Policy and Practice in Post-apartheid South Africa, Heinemann Publishers (Pty) Ltd, Sandown.

Knight, R., 2002, 'The black dispossession in South Africa: The myth of Bantustan independence', Southern Africa Perspectives \& Africa Fund 4(2), 11.

Ledeneva, A. \& Kurkchiyan, M., 2000, Economic crime in Russia, pp. 99-111, Kluwer Law International, London.

Lindsell, D., 2007, 'A place to call home - Enabling dignified communities', Black Business Quarterly 33(3), 73.

Lipton, R. \& Gruenewald, P.J., 2002, 'The spatial dynamics of violence and alcoho outlets', Journal of Studies on Alcohol 63(1), 187-195. https://doi.org/10.15288/ jsa.2002.63.187

Malik, S. \& Wahid, J., 2014, 'Rapid urbanization: Problems and challenges for adequate housing in Pakistan', Journal of Sociology and Social Work 2(2), 87-110. https:// doi.org/10.15640/jssw.v2n2a6

Malpass, P., 1990, The housing crisis, Routledge, London.

Masilela, E., 2012, Rationale and challenges in delivering affordable housing in South Africa, IHC Conference, 03 October 2012, Johannesburg Country club, Johannesburg.

Matunhu, J., 2008, 'Xenophobic attacks in South Africa', African Journal of Criminology and Justice Studies 5(2), 96-108.

May, J., Carter, M. \& Padayachee, V., 2004, 'Is poverty and inequality leading to poor growth?', South African Labour Bulletin 28(2), 18-20.

Meth, P., 2016, 'Informal housing, gender, crime and violence: The role of design in Urban South Africa', The British Journal of Criminology 57(2), 402-421. https:// doi.org/10.1093/bjc/azv125

Mhone, G. \& Edigheji, O., 2003, Governance in the new South Africa: The challenges of globalisation, University of Cape Town Press, Lansdowne.

Misselhorn, M., 2010, A new response to informal settlements. "The Transformer", Afesis-corplan, Cape Town.

Morka, F., 2018, The right to adequate housing, Human Rights Resource Centre, University of Minnesota, Minneapolis, MN.

Mullins, P., Western, J. \& Broadbent, B., 2001, 'The links between housing and nine key socio-cultural factors: A review of the evidence positioning paper', prepared by the Australian Housing and Urban Research Institute Queensland Research Centre, AHURI Positioning Paper No. 4 ISSN 1834-9250, Queensland Research Centre, Queensland.

Musewe, T., 2012, 'Housing our people: Developing adequate housing for Africans,' Mobilitate 15(5), 37.

Napier, M., 1993, 'Housing problem in South Africa - Ideological perspectives', Forum 2(1) 8 .

Nathan, O., 2013, Building revolutionary working class counter power: Municipalities, service delivery and protest, Zabalaza, Cape Town.

PADCO, 2006, Housing for all: Essential to economic, social, and civic development, viewed n.d., from https://www.habitat.org/lc/housing_finance/pdf/housing_for_ all.pdf.

Phago, K., 2010, 'The development of housing policy in South Africa', Politeia 29(3), 88-106.

Power, A., 1993, Hovels to high rise - State housing in Europe since 1850, Routledge, London.

Provincial Budgets and Expenditure Review, 2010, Provincial budgets and expenditure review, 2010, 2003/04 - 2009/10, Housing, pp. 69-72, Government Printers, Pretoria.

Raymond, J., Wheeler, W. \& Jean-Brown, M., 2011, 'Inadequate and unhealthy housing, 2007 and 2009', Morbidity and Mortality Weekly Report 60(01), 21-27.

Republic of South Africa, 1996, Constitution of the Republic of South Africa, 1996 Government Printers, Pretoria.

Republic of South Africa, 2010, Provincial Budgets and Expenditure Review: 2003/2004 - 2009/2010: Housing, pp. 69-72, Government Printers, Pretoria.

Republic of South Africa, 2018, South Africa Year-Book, 2017/2018: Human settlements, p. 9, viewed n.d., from https://www.gcis.gov.za/sites/default/files/ docs/resourcecentre/yearbook/13-HumanSettlements2018.pdf.

Robbins, S., Bergman, R., Stagg, I. \& Coulter, M., 2008, Management, 5th edn., Pearson Education, Melbourne.

Rodgers, D., 2001, Cooperative housing, Routledge, Meuthen.

Rodwin, L., 1987, Shelter, settlements, and development, Allen Unwin, Boston, MA.

Setplan, 2008, Densification framework - status quo: Analysis and findings document for Ekurhuleni Metropolitan Municipality, pp. 38-68, Council for Scientific and Industrial Research, Johannesburg.

Shaw, M., 2003, Housing and public health, Department of Social Medicine, University of Bristol, Bristol.
Social Work Policy Institute, 2006, Social Work Policy Institute, 2006, The National Association of Social Workers Foundation (NASWF), Washington, DC.

Sokupa, T., 2009, 'Let us have better coordination of inter-governmental relations', The Transformer 1(1), 7-10.

South African Institute of Race Relations, 2009, South Africa Survey 2008-2009: Living conditions and communications - Housing, South African Institute of Race Relations, Johannesburg.

South Africa Survey 2008/9, South Africa Year-Book, 2008/09, Human settlements, p. 308, Government Printers, Pretoria.

South Africa Year Book 2017/18, South Africa Year-Book, 2017/18, Human settlements, p. 347, Government Printers, Pretoria.

Statistics South Africa's Household Survey, 2017, pp. 111-115, Government Publishers, Pretoria.

Steenekamp, T., 2012, The South African economy, Oxford University Press, Cape Town.

Stoner, J.A.F., Freeman, A.E. \& Gilbert, D.A., 1995, Management, 6th edn., Prentice Hall International, Canada.

Tariq, F., 2012, Facilitating community development with housing microfinance: Appraising housing solutions for Pakistan after disasters, College of Design, NC State University, Raleigh, NC.

The Housing Development Agency, 2018, Informal settlements status, The Housing Development Agency, Johannesburg.

Tibaijuka, A.K., 2009, Building prosperity: Housing and economic development, Taylor and Francis Publishers, New York, NY

Tshitekere, C., 2008, 'The importance of adequate housing', Mail \& Guardian, October, Johannesburg.

UN-Habitat, 2008, Milestones in the Evolution of human settlements policies: State of the world cities: Report 2007/2008, Routledge, New York, NY.

UN-Habitat, 2009, Informal settlements: Report 30 May 2009, Routledge, New York, NY.

UN-Habitat, 2014, Informal settlements: Report 31 May 2014, Routledge, New York, NY.

UN-Habitat, 2015, Informal settlements: Report 31 May 2015, Routledge, New York, NY.

United Nations Centre for Human Settlements (Habitat) and International Labour Organization (ILO), 1995, Shelter provision and employment generation, ILO Publication, Nairobi.

United Nations Millennium Project, 2005, Women and the right to adequate housing, United Nations, Geneva.

United Nations Publication, 2012, Women and the right to adequate housing, United Nations, Geneva.

University of Dublin, Trinity College, 2015, Slums and informal settlements, viewed 26 November 2015, from https://www.tcd.ie/Economics/Development studies/ link.php?ld=92

Van der Waldt, G. \& Du Toit, D.F.P., 1997, Managing for excellence in the public sector, Juta and Company Limited, Kenwyn.

Ward, P., 2001, 'The rehabilitation of consolidated irregular settlements in Latin American cities: Towards a third generation of public policy housing analysis and development', paper presented at the ESF N AERUS International Workshop on Coping with Informality and Illegality in Human Settlements in Developing Cities, 26 May 2001, viewed $n \cdot d$ from $h t t p s: / / w w w . g o o g l e . c o m / u r l ? s a=t \& r c t=j \& q=\& e s$

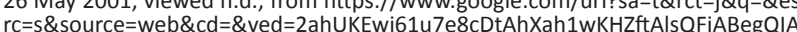
xAC\&url=http\%3A\%2F\%2Fn-aerus.net\%2Fweb\%2Fsat\%2Fworkshops\%2F2001\%2 Fpapers\%2Fward.rtf\&usg=AOvVaw1YyET1- 1PPYdvm7JGSQzPG

White Paper on Housing, 1994, A new housing policy and strategy for South Africa, pp. 1-55, Government Printers, Pretoria.

Wilkinson, P., Armstrong, B. \& Landon, M., 2001, Cold comfort: The social and environmental determinants of excess winter deaths in England, 1986-1996, Policy Press, London.

Wilkinson, P., Close, R. \& Crabbe, H., 2016, The health problems associated with poor housing and home conditions, flooding, poor sanitation and water pollution, Health Knowledge, New York, NY.

Wimmer, A., 1997, 'Explaining xenophobia and racism: A critical review of current research approaches', Ethnic and Racial Studies 20(1), 10. https://doi.org/10.1080/ 01419870.1997.9993946

Young, B., 2004, Housing policy systems in South and East Asia, Macmillan, Palgrave. Yuen, B., 2002, Housing policy systems in South and East Asia, Macmillan, Palgrave.

Zanganeh, M., Varesi, H.R. \& Zangiabadi, A., 2013, 'Strategic housing planning through sustainable development approach in Iran metropolitans: Case study of metropolitan Mashhad', Journal of Basic and Applied Scientific Research 3(9), 180-188. 